We thank the Nuffield Department of Biochemistry and colleagues at the Oxford Haemophilia Centre for help with the study; $\mathrm{Mr}$ Roger Matchett for devising the figure; and Mrs Mary Bourton for preparing the typescript. MLF is supported by a research grant from the National Health Service locally organised research scheme of the Oxford Regional Health Authority.

\section{References}

${ }^{1}$ Biggs R. Jaundice and antibodies directed against factor VIII and IX in patients treated for haemophilia or Christmas disease in the United Kingdom. Br 7 Haematol $1974 ; 26: 313-29$.

${ }^{2}$ Craske J, Spooner R. Evidence for existance of at least two types of factor VIII-associated non B transfusion hepatitis. Lancet 1978;ii:1051-2.

${ }^{3}$ Craske J, Kirk P, Cohen B, Vandervelde EM. Commercial factor VIII associated hepatitis $1974-75$ in the United Kingdom: a retrospective study. F Hyg (Lond) 1978;80:327-36.

${ }^{4}$ Craske J. The epidemiology of factor VIII and IX associated hepatitis in the UK. In: Forbes CD, Lowe GDO, eds. Unresolved problems in haemophilia. Lancaster: MTP Press, 1982:5-14.

${ }^{5}$ Giorgini GL Jr, Hallinger FB, Ledugh IS, George J, Blackman A, Thayer WR. A prospective study in blood donors and recipients. f AMA 1972;222:1514-8.

${ }^{6}$ Mosley JW, Redeker AG, Feinstone SM, Purcell RH. Multiple hepatitis viruses in multiple attacks of acute viral hepatitis. $N$ Engl f Med 1977; $296: 75-8$

${ }^{7}$ Bradley DW, Maynard JE, Cook EH, et al. Non-A/non-B hepatitis in experimentally infected chimpanzees: cross challenge and electron microscopic studies. F Med Virol 1980;6:185-201.

${ }^{8}$ Tsiquaye KN, Zuckerman AJ. New human hepatitis virus. Lancet 1979; i:1135.

9 Yoshizawa H, Itoh Y, Iwaakiri S, et al. Demonstration of two different types of non-A non-B hepatitis by reinjection and cross-challenge studies in chimpanzees. Gastroenterology 1981 ;81:107-13.

${ }^{10}$ Henry RJ, Chiamori K, Colub OJ, Bestimanar S. Revised spectrophotometric methods for the determination of glutanic-oxalacetic transaminase, gluanic-pyravic transaminase and lactic acid dehydrogenase. Am 7 Clin Pathol 1960;34:381-9.

11 Anonymous. Zeitschrift für Klinische Chemie und Klinische Biochemie $1970 ; 8: 658$

12 Anonymous. Zeitschrift für Klinische Chemie und Klinische Biochemie $1972 ; 10: 182$.

${ }^{13}$ Lane RS. Hepatitis B surface antigen testing: the blood products laboratory radioimmunoassay (BPL/RIA) system. Med Lab Sci $1981 ; 38$. 323-9.

14 Bradstreet CMP, Taylor CED. Technique of complement-fixation test applicable to the diagnosis of virus disease. Monthly Bulletin of the Ministry of Health and the Public Health Laboratory Service 1962;21. 96-104.

${ }^{15}$ Henle G, Henle W. Immunofluorescence in cells derived from Burkitt's lymphoma. $\mathcal{F}$ Bacteriol 1966;91:1248-56.

${ }^{16}$ Bamber M, Murray A, Arborgh BAM, et al. Short incubation non-A non-B hepatitis transmitted by factor VIII concentrates in patients with congenital coagulation disorders. Gut 1981 ;22:854-9.

(Accepted 14 September 1983)

\title{
Perthes' disease of the hip in Liverpool
}

\author{
A J HALL, D J P BARKER, P H DANGERFIELD, J F TAYLOR
}

\begin{abstract}
A survey of Perthes' disease of the hip in three regions of England showed a higher incidence in the Mersey region compared with Trent or Wessex. To explore this further a case register was set up in Liverpool. Analysis of all new cases that occurred in Liverpool and adjacent parts of Knowsley and Sefton during 1976-81 showed a steep gradient with social class, ranging from $7 \cdot 7 / 100000$ children in the higher classes to $26 \cdot 3 / 100000$ in social class $V$. The inner city of Liverpool, which has been shown to be underprivileged, had the highest yearly incidence of the disease ever reported-21.1 cases/100 000 children aged 14 years and under.

The associations with poverty support the hypothesis that undernutrition is a causative factor in the disease.
\end{abstract}

MRC Environmental Epidemiology Unit, University of Southampton, Southampton General Hospital, Southampton SO9 4 XY

A J HALL, MSC, MRCP, Wellcome research training fellow in clinical epidemiology

D J P BARKER, PHD, FRCP, professor of clinical epidemiology

University Department of Human Anatomy, Liverpool

P H DANGERFIELD, $\mathrm{MB}$, $\mathrm{CHB}$, lecturer

Alder Hey Children's Hospital, Liverpool

J F TAYLOR, MD, FRCS, consultant orthopaedic surgeon

Correspondence to: Dr A J Hall.

\section{Introduction}

The aetiology of Perthes' disease of the hip is unknown. A survey of its incidence in three regions of England during 1976 showed a yearly rate of $11 \cdot 1$ cases $/ 100000$ children aged under 15 in Mersey compared with 7.6 in Trent and 5.5 in Wessex. ${ }^{1}$ The incidences were higher within the conurbations of Merseyside and South Yorkshire than elsewhere in the Mersey and Trent regions. In order to explore further the apparent high incidence in Merseyside a register was set up in Liverpool. This paper describes an analysis of all new cases registered during 1976-81.

\section{Methods}

The cases comprised inpatients and outpatients attending the Royal Liverpool Children's Hospital and the Alder Hey Hospital from 1 January 1976 to 31 December 1981. This analysis is confined to children resident in Liverpool City or in the adjacent areas of Knowsley and Sefton Districts, which at the outset of the survey were deemed to be within the exclusive catchment area of the two hospitals. Radiological criteria for the diagnosis of the disease were established at the inception of the register with the help of an independent observer. To ensure completeness of the register, which depended primarily on collaboration with orthopaedic surgeons, diagnostic registers in the medical records departments of the two hospitals, operating lists, and Hospital Activity Analysis data for the Mersey region were searched.

In 1982 a questionnaire was sent to the mothers of the children. The information requested included place of residence at the birth of the child and occupation of the father. When a mother failed to respond, usually because of change of address, she was visited at home.

Incidence rates for each of the 57 electoral wards were calculated using population data from the small area statistics of the 1981 Census of England and Wales. These statistics also provided data on 
social class distribution, unemployment, overcrowding, and population density in the wards. Because of unemployment some children could not be assigned to a social class in the census. For this study such children were assigned to social classes in proportion to the social class distribution of the particular wards. Standardisation of rates for social class was effected using the indirect method with the class specific rates for the study area as the standard.

Analysis of space-time clustering was carried out to determine whether cases occurring in any one part of the city tended to occur at around the same time. The analysis was carried out in two ways. Using the Ederer-Myers-Mantel method, ${ }^{2}$ we subdivided the study area into nine sub-areas of equal size and compared the numbers of cases in each sub-area over single years. To apply the Knox method of close pairs ${ }^{3}$ the map grid reference of each address was obtained and the numbers of pairs examined in intervals of 0.5 kilometre and three months.

\section{Results}

During the six years 157 children within the study area were registered as new cases of Perthes' disease, giving an average yearly incidence of 15.6 cases $/ 100000$ children aged 14 years and under. Of these children, 133 were boys and 24 girls, giving incidences of 25.8 and 4.9 cases $/ 100000$ respectively, a ratio of 5.3 to 1 . No cases occurred under the age of 2 years or over the age of 12 (table I). The peak age at the time of diagnosis was 5 years for boys (incidence $91 / 100000$ ) and 4 years for girls (incidence 19/100 000). The median ages were 5 years 11 months for boys and 5 years 1 month for girls.

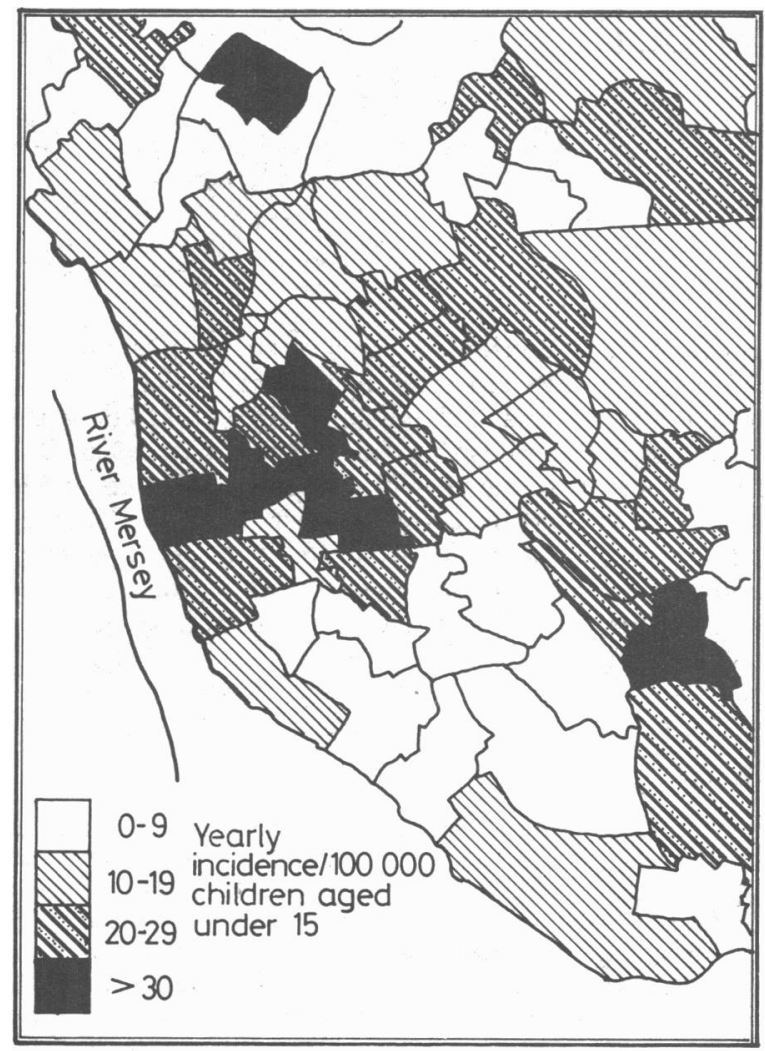

FIG 1-Average yearly incidences of Perthes' disease per 100000 children aged 14 and under in electoral wards in Liverpool and adjacent areas of Merseyside.
Applying the age specific rates to the population gave a cumulative attack rate of 1 in 375 children in Liverpool.

Figure 1 shows the incidence rates by ward. In eight wards there were no cases: in five the incidence was greater than 30 , one of these (Netherley) being an area of new housing in which people from the inner city had been resettled. There was an aggregation of incidences of 20 or more per 100000 in the inner city area close to the Mersey. A map based on place of residence at birth rather than at the time of diagnosis was closely similar.

Figure 2 shows the wards aggregated into four administrative areas, Liverpool inner city (as defined by the city's planning office), outer Liverpool, and those parts of Knowsley and Sefton Districts included in the study. The incidence in the inner city was $21 \cdot 1$ compared with $13.1,14.6$, and 11.9 in the three other areas (fig 2; table II).

Table III shows the social class distribution. For $25(16 \%)$ of the cases information on social class was obtained by home visit rather than reply to the postal questionnaire: only one child could not be

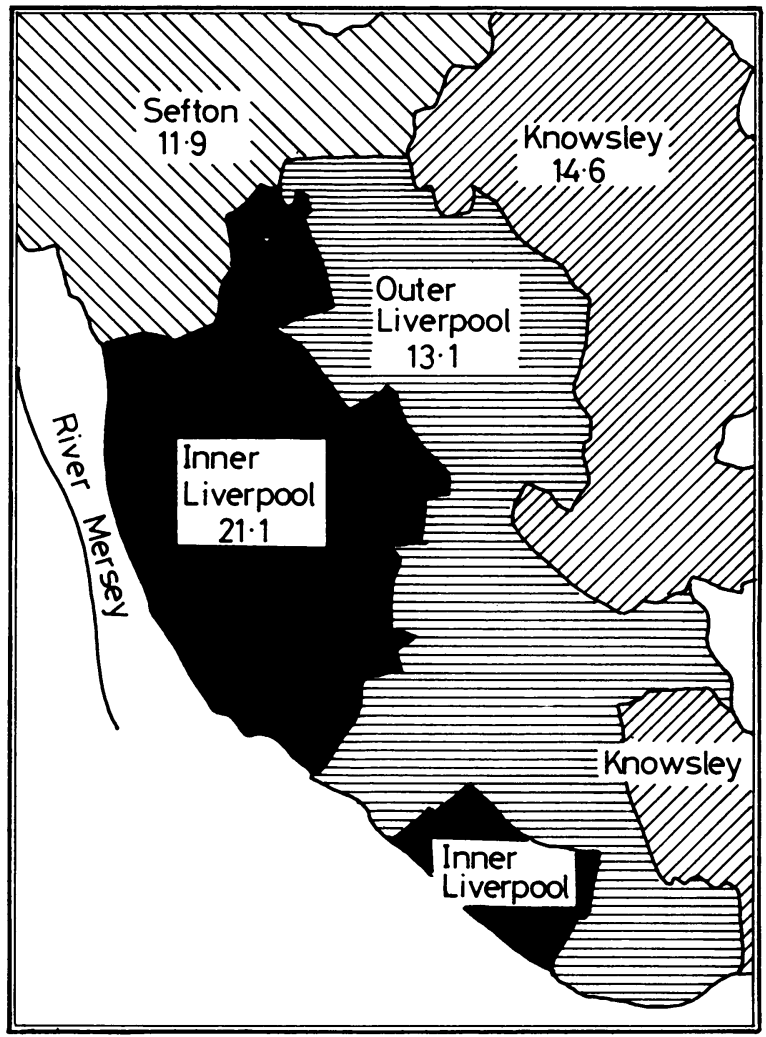

FIG 2-Average yearly incidences of Perthes' disease per 100000 children aged 14 and under in administrative areas.

TABLE II-Average yearly incidences of Perthes' disease per 100000 children aged 14 and under in various geographical areas. (Figures in parentheses are numbers of cases)

\begin{tabular}{lcc}
\hline \multicolumn{1}{c}{ Geographical area } & Crude rate & Rate standardised for social class* \\
\hline Inner Liverpool & $21 \cdot 1(65)$ & $19 \cdot 3$ \\
Outer Liverpool & $13.1(38)$ & 13.5 \\
Wards in Knowsley District & $14.6(31)$ & $13 \cdot 4$ \\
Wards in Sefton District & $11.9(23)$ & 11.9 \\
\hline
\end{tabular}

*See text.

\begin{tabular}{|c|c|c|c|c|c|c|c|c|c|c|c|c|c|c|c|c|}
\hline & \multicolumn{15}{|c|}{ Age in years } & \multirow{2}{*}{ All ages } \\
\hline & 0 & 1 & 2 & 3 & 4 & 5 & 6 & 7 & 8 & 9 & 10 & 11 & 12 & 13 & 14 & \\
\hline $\begin{array}{l}\text { Boys } \\
\text { Girls }\end{array}$ & $\begin{array}{l}0 \\
0\end{array}$ & $\begin{array}{l}0 \\
0 \\
0\end{array}$ & $\begin{array}{l}23.6 \\
14.3\end{array}$ & $\begin{array}{l}55.0 \\
11.5\end{array}$ & $\begin{array}{l}73.2 \\
18.8\end{array}$ & $\begin{array}{l}91.3 \\
14.6\end{array}$ & $\begin{array}{l}80 \cdot 7 \\
17 \cdot 8\end{array}$ & $\begin{array}{r}26.1 \\
6.7\end{array}$ & $\begin{array}{r}35 \cdot 1 \\
3 \cdot 1\end{array}$ & $\underset{0}{26 \cdot 9}$ & $\begin{array}{c}17 \cdot 7 \\
0\end{array}$ & $5 \cdot 1$ & $2 \cdot 5$ & $\begin{array}{l}0 \\
0\end{array}$ & $\begin{array}{l}0 \\
0\end{array}$ & $\begin{array}{rr}25.8 & (133) \\
4.9 & (24)\end{array}$ \\
\hline
\end{tabular}


traced. Because of small numbers classes I, II, and III non-manual were combined. In the study area as a whole the incidence rose progressively from 7.7 in the combined group to 26.3 in social class V. This steep rise in incidence from high to low social class was seen both in Liverpool inner city and in the remaining wards combined. Inner city rates, however, were higher within each social class, reaching 31.7 in social class V. Standardisation for social class had little effect on the overall rate in the inner city (table II). Analyses by sex showed that the patterns of distribution by geographical area and social class were similar for boys and girls.

Linear regression analyses of social class standardised incidences

TABLE III-Average yearly incidences of Perthes' disease per 100000 children aged 14 and under distributed by social class and geographical area. (Figures in parentheses are numbers of cases)

\begin{tabular}{lcccc}
\hline \multirow{2}{*}{ Geographical area } & \multicolumn{5}{c}{ Social class* } \\
\cline { 2 - 5 } & I, II, IIIN & IIIM & IV & V \\
\hline Inner Liverpool & $10 \cdot 3(5)$ & $20 \cdot 1(24)$ & $30 \cdot 3(21)$ & $31 \cdot 7(14)$ \\
All other wards & $7 \cdot 4(13)$ & $14 \cdot 3(37)$ & $18 \cdot 1(26)$ & $21 \cdot 8(16)$ \\
\hline Total & $7 \cdot 7(18)$ & $16 \cdot 0(61)$ & $22 \cdot 3(47)$ & $26 \cdot 3(30)$
\end{tabular}

*Social class of one child not determined. $\mathrm{N}=\mathrm{Non}$-manual.

on population density of wards (expressed as persons per hectare) and overcrowding (as measured by the proportion of households with more than one person per room) gave positive correlations. For population density the correlation coefficient was $0.27(p<0.05)$; for overcrowding it was $0.29(\mathrm{p}<0.05)$.

There was no seasonal pattern of variation in incidence either by month of diagnosis or by month of birth. Likewise, the space-time analyses showed no evidence of clustering at the time of diagnosis or birth.

\section{Discussion}

This study of the occurrence of Perthes' disease in Liverpool during a six year period showed a high yearly incidence of 15.6 cases $/ 100000$ children aged 14 years and under. This accords with the results of the previous regional survey, which showed an incidence of 11.1 in the Mersey region compared with 7.6 in Trent and 5.5 in Wessex. ${ }^{1}$ These rates are comparable with those of $5 \cdot 7$ recorded in Massachusetts, ${ }^{4} 5 \cdot 1$ recorded in British Columbia, ${ }^{5}$ and 10.8 among whites in Eastern Cape, South Africa. ${ }^{6}$ The male preponderance of the disease in Liverpool (roughly 5 to 1 ) was similar to that in the other surveys, as was the age distribution.

We think that the level of ascertainment in our survey, which depended on a register of patients attending hospital, was likely to be high, as in other surveys. Parents are unlikely to ignore a persistent, painful, and unexplained limp, nor general practitioners treat it without referral for a specialist opinion.

There was an aggregation of cases in inner Liverpool, where the incidence of $21 \cdot 1$ cases $/ 100000$ (table II) was the highest ever reported. The disease had a remarkably steep social class gradient in Liverpool, ranging from $7 \cdot 7$ in classes I, II, and IIIN combined (a similar incidence to those recorded in other populations) to 26.3 in class V (table III). An association with low social class was suggested from a case series in Edinburgh and Glasgow," but those data did not allow calculation of rates specific for social class.

The distribution of incidences by ward were largely independent of social class (table II) but correlated with population density and overcrowding. The map of the disease in Liverpool (fig 2) was strikingly similar to Jarman's map of underprivilege. ${ }^{8}$ That map was produced from a composite score of intercorrelated social variables such as unemployment and poor housing. It demonstrated the concentration of underprivilege in the inner city. The correlation coefficient between incidence and composite score by ward was $0.56(\mathrm{p}<0.001)$.
An inference from these findings is that there are factors in the aetiology of the disease which are associated with povertyboth the poverty of low social class and, independently, that attendant on living in an underprivileged area.

Infection has been suggested as a cause of Perthes' disease. ${ }^{\circledR}$ The absence of seasonality in our data and of space-time clustering, either in residence at the time of onset or at birth, does not support this. In a study of the numbers of cases of Perthes' disease seen in Dortmund, West Germany, from 1924 to 1960 Peic related peaks to periods of economic recession and suggested that undernutrition might predispose to the disease. ${ }^{10}$ The results of recent anthropometric studies are consistent with this hypothesis in that they have shown children with Perthes' disease to be shorter than controls of similar age, even after allowance is made for parental stature. ${ }^{711}$

Our findings of a high incidence of the disease in the most socially deprived part of Liverpool, a high incidence in the low social classes, and, in the regional survey, a higher urban than rural incidence, support the hypothesis that undernutrition is an aetiological influence.

We are grateful to Dr D C Pinder, of the Mersey Regional Health Authority, for supplying the Hospital Activity Analysis data and to Mrs D Knight, of Liverpool City Planning Office, for population data. Dr B Jarman and Doreen Irving kindly gave us unpublished data on their underprivilege score. Dr C Osmond gave statistical advice.

\section{References}

${ }^{1}$ Barker DJP, Dixon E, Taylor JF. Perthes' disease of the hip in three regions of England. F Bone foint Surg $(B r)$ 1978;60:478-80.

2 Ederer F, Myers MH, Mantel N. A statistical problem in space and time: do leukaemia cases come in clusters ? Biometrics $1964 ; 20: 626-38$.

${ }^{3}$ Knox EG. The detection of space-time interactions. Applied Statistics $1964 ; 13: 25-9$.

4 Molloy MK, MacMahon B. Incidence of Legg-Perthes' disease. N Engl f Med 1966;275:988-90.

5 Gray IM, Lowry RB, Renwick DHG. Incidence and genetics of LeggPerthes' disease. $\mathcal{F}$ Med Genet 1972;9:197-202.

- Purry NA. The incidence of Perthes' disease in three population groups in the Eastern Cape region of South Africa. $\mathcal{F}$ Bone foint Surg $(B r)$ $1982 ; 64: 286-8$.

7 Wynne-Davies R, Gormley J. The aetiology of Perthes' disease. $\mathcal{F}$ Bone foint Surg $(B r)$ 1978;60:6-14.

8 Jarman B. Identification of underprivileged areas. $\mathrm{Br}$ Med $\mathcal{f} 1983 ; 286$ : 1705-9.

9 Matsoukas J. Viral antibody titres to rubella in coxa plana or Perthes' disease. Acta Orthop Scand 1975;46:957-62.

10 Peic S. Beitrag zur Perthesschen erkrankung. Z Orthop 1962;96:276-82.

11 Burwell RG, Dangerfield PH, Hall DJ, Vernon CL, Harrison MHM Perthes' disease. An anthropometric study revealing impaired and disproportionate growth. F Bone foint Surg $(B r)$ 1978;60:461-77.

(Accepted 18 October 1983)

SPIRIT AND WATER OF WORMWOOD-"Take of the leaves of dryed Wormwood two pounds, Annis seeds, half a pound: steep them in six gallons of small wine twenty four hours, then distil them in an Alembick, adding to every pound of the distilled water two ounces of the best Sugar.

Let the two first pound you draw out be called Spirit of Wormwood, those which follow, Wormwood water the lesser composition."

I like this distinction very well, because what is first stilled out, is far stronger than the rest, and therefore very fitting to be kept by itself: you may take which you please, according as the temperature of your body, either to heat or cold, and the season of year requires.

It hath the same virtues Wormwood hath, only fitter to be used by such whose bodies are chilled by age, and whose natural heat abates. You may search the herbs for the virtues, it heats the stomach, and helps digestion. (Nicholas Culpeper (1616-54) The Complete Herbal, 1850.) 